successful than in non-diabetics. More encouraging results have come from transplantation from live related donors. Experience of transplantation in Britain has been extremely limited-perhaps the limitation is the long waiting list for non-diabetics. Criteria for selection have yet to be determined; indeed at the Mayo Clinic the procedure for the last six years has been to select patients on an individual basis irrespective of factors such as retinopathy, neuropathy, ischaemic heart disease, or age. ${ }^{18}$

Diabetic renal damage is (almost without doubt) a consequence of the metabolic derangements of diabetes, and histological examination of renal grafts two years after transplantation has shown the hyalinosis of both efferent and afferent arteries that is characteristic of long-term diabetes. ${ }^{19}$ Hyperglycaemia is probably the main determinant of basement membrane disease, ${ }^{20}$ which is the first step in the nephropathy. While the relevance of animal experiments to human disease is still a matter of dispute islet transplantation in inbred diabetic rats effectively returns glucose and insulin concentrations to normal-and causes a rapid regression of the light microscopic and immunopathological glomerular lesions. ${ }^{21}$ A combination of islet cell transplantation with renal transplantation may repay investigation. The future may well hold considerable promise for the diabetic in terms of preventing or removing the renal component of microvascular disease. Meanwhile, conventional treatment to control the metabolic derangements and to prevent or treat urinary tract infections can be pursued with greater optimism.

${ }^{1}$ Entmacher, P S, Root, H F, and Marks, H H, Diabetes, 1964, 13, 373.

${ }^{2}$ Deckert, T, and Poulsen, J E, Acta Medica Scandinavica, 1968, 183, 351.

${ }^{3}$ Kussman, M J, Goldstein, H, and Gleason, R E, Fournal of the American Medical Association, 1976, 236, 1861.

${ }^{4}$ Wilson, J L, Root, H F, and Marble, A, New England fournal of Medicine, 1951, 245, 513.

${ }^{5}$ Knowles, H C, Kidney International, 1974, 6, suppl 1, S2.

${ }^{6}$ Shapiro, F L, Leonard, A, and County, C M, Kidney International, 1974, 6, suppl 1, S8.

' Blumenkrantz, M J, et al, Kidney International, 1974, 6, suppl 1, S108.

${ }^{8}$ Von Hartitzsch, and Medlock, T R, Transactions. American Society for Artificial Internal Organs, 1976, 22, 595.

${ }^{9}$ Oreopoulos, D G, et al, Proceedings of the Dialysis and Transplant Forum, $1975,5,142$.

10 Woods, J E, et al, Lancet, 1972, 2, 795.

11 Kjellstrand, C M, et al, Lancet, 1973, 2, 4

12 Shideman, J R, Buselmeier, T J, and Kjellstrand, C M, Archives of Internal Medicine, 1976, 136, 1126.

${ }_{13}$ Kjellstrand, C M, et al, Kidney International, 1974, 6, suppl 1, S15.

14 Matas, A J, et al, American fournal of Surgery, 1975, 129, 616.

15 Simmons, R L, et al, Urologic Clinics of North America, 1976, 3, 691.

16 Wilson, R E, et al, Kidney International, 1974, 6, suppl 1, S90.

17 Weinrauch, L A, et al, Annals of Internal Medicine, 1978, 88, 346.

${ }_{18}$ Zincke, H, et al, fournal of the American Medical Association, 1977, 237, 1101 .

19 Mauer, S M, et al, New England Fournal of Medicine, 1976, 295, 916.

${ }^{20}$ Fox, C J, et al, British Medical fournal, 1977, 2, 605.

${ }^{21}$ Mauer, S M, Diabetes, 1975, 24, 280.

\section{Road accidents: the unnecessary epidemic?}

Man's brain did not evolve to cope with traffic, and the motorist has been described as a centaur, a man grafted on to a machine. ${ }^{1}$ But, though road accidents may always be with us, there is no place for complacency, and they are better regarded as epidemic rather than as endemic. For example, they are especially prevalent in certain age groups, at certain times of the day and the week, and at certain locations; some people may be more susceptible than others and susceptibility is increased by the effects of alcohol and other drugs, as well as physiological states such as fatigue.

The latest road casualty statistics show that the rising trend of the last few years continues, with $2 \%$ more casualties in the second quarter of 1978 than of 1977 . Though the casualty rate fell slightly between 1975 and 1977, the total distance driven or ridden increased and so did the total casualties-from 325000 to $348000 .^{2}$ Is this the inescapable price of our way of life and increasing affluence?

As with any epidemic, investigators should be able to point to the responsible factors and hence effective prevention. This is, of course, an oversimplification, because some factors, such as the behaviour and aberrations of drivers, are complex and do not lend themselves to simple solutions. Nevertheless, the lessons of research have not been fully exploited and acted on, and undoubtedly we could prevent loss of life and suffering by applying the knowledge we already have. In the series of 12 articles starting on $\mathrm{p} 1199$ we aim at drawing attention to some of the problems and possibilities. There are two particular needs. Firstly, things are not always what they seem: for instance, are pedestrian accidents common at junctions because these are more dangerous than other crossing places or because, though relatively safe, more people cross there ? If we get the answers wrong supposed safety measures may actually create hazards. To find out the facts scientifically is therefore of paramount importance. Secondly, when we know the facts they must be acted on without delay. Though we have made great strides in improving road safety, this obvious principle is often ignored, as the lamentable history of the seat belt in Britain attests.

Nevertheless, there is another important aspect to road accidents: that people are not keeping the laws already passed that were intended for the good of the individual in particular and of society in general. Stand, say, at any busy road junction in the rush hour: at a pedestrian crossing cars may be obstructing pedestrians or parked so that oncoming traffic cannot see them; cars or lorries may be travelling above the speed limits; they may be moving or parked in bus lanes, causing sudden diversions by buses and danger to cyclists; they may straddle box junctions; obstructing the traffic flow; vehicles may be turning illegally where no such turn is allowed, while many others may be breaking the law by not having the stipulated number of lights or being too noisy or polluting. For their own part, also, pedestrians may be adding to the dangers by jaywalking against a red light ordering them to stop.

By themselves, the police are relatively powerless to control such behaviour: as most chief constables emphasise in their reports, society has the paramount role in following the recognised code. Some of these illegal practices, however, are more dangerous than others, and in a separate feature accompanying each article, "If preventable, why not prevented ?" we plan to examine the part played by some of these abuses in causing injury and death. In some ways, compared with other countries, the British have relatively good road-accident statistics: an EEC report ${ }^{3}$ shows that the number of drivers and passengers killed in 1976 was less than half that in either France or Germany. On the other hand, our pedestrian toll is the highest in Europe. We hope to examine the various factors responsible for these statistics in the next few months and to suggest some ways of making things better.

${ }^{1}$ Cohen, J, and Preston, B, Causes and Prevention of Road Accidents, ch. 2. London, Faber and Faber, 1968

${ }^{2}$ Department of Transport, Roads to Safety, p 18. London, Department of Transport, 1978.

${ }^{3}$ See Daily Mail, 10 October 1978, p 3. 